\title{
KH. ACHMAD ZAMACHSYARI, LEADERSHIP, AND MODERNIZATION OF PESANTREN: Character Study in Al-Rifa'ie Modern Islamic Boarding School of Malang
}

\author{
Devi Pramitha \\ Universitas Islam Negeri Maulana Malik Ibrahim Malang, Indonesia \\ E-mail: devipramitha@uin-malang.ac.id
}

\section{Abstract}

KH. Achmad Zamachsyari or Gus Mad became one of the initiators to make changes by establishing a modern Islamic boarding school in Malang. He leads, provides a vision to move toward improvement and change. He chose an area in Ketawang, Gondanglegi, Malang to begin his struggle to build a modern Islamic boarding school. This study aims at obtaining a complete description of Gus Mad's leadership behavior; his interaction patterns; and modernization concept of Islamic boarding school education. The research design is qualitative and it uses the character study method. Gus Mad was chosen as the object of research because he was one of the Kiais in Malang who made a change, namely from the leader of the Al-Fattah Singosari Salafiyah then founded the Al-Rifa'ie Modern Islamic boarding school. Data obtained by interviews, documents, and observation. Data analysis used the Spradley model, consisting domain, taxonomic, component and theme analyses. Three findings are (1) Gus Mad's behavior at Al-Rifa'ie leads to transformational leadership; (2) his interaction pattern at Al-Rifa'ie led to traditional leadership; and (3) hisconcept of modernization of Islamic boarding school education is based on the principles of al-Muhâfazat 'alâ alqadîm alsâalih wa al-akhdhu bi al-jadîd al-aslah. Gus Mad's leadership style at Al-Rifa'ie Modern Islamic Boarding School Malang is a neotransformationalism leadership style, a combination of transformationalism 
and traditionalism leadership style based on the principles of al-muhâfazat 'alâ al-qadîm al-sâlih wa al-akhdhu bi al-jadîd al-aslah.

KH. Achmad Zamachsyari atau Gus Mad merupakan salah satu inisiator pembangunan pondok pesantren modern di Malang. Beliau menjadi seorang pemimpin, memberikan visi untuk bergerak menuju perbaikan dan perubahan. Gus Mad memilih daerah di Ketawang, Gondanglegi, Malang untuk memulai perjuangannya membangun pondok pesantren modern. Penelitian ini bertujuan memperoleh deskripsi lengkap tentang perilaku kepemimpinan; pola interaksi; dan konsep modernisasi pendidikan pesantren perspektif Gus Mad. Jenis penelitian adalah penelitian kualitatif dan menggunakan metode studi tokoh. Gus Mad dipilih sebagai objek penelitian karena beliau merupakan salah satu Kiai di kota Malang yang melakukan suatu perubahan dari pemimpin pondok pesantren salafiyah Al-Fattah Singosari kemudian mendirikan pondok pesantren modern Al-Rifa'ie Malang. Data diperoleh dengan wawancara, dokumentasi dan observasi. Analisis data menggunakan model Spradley yang terdiri dari analisis domain, analasis taksonomi, analisis komponensial dan analisis tema. Tiga hasil temuan yaitu, (1) perilaku Gus Mad di PPM Al-Rifa'ie mengarah kepada kepemimpinan transformasional; (2) pola interaksi Gus Mad di PPM Al-Rifa'ie mengarah kepada kepemimpinan tradisional; dan (3) konsep modernisasi pendidikan pesantren perspektif Gus Mad berdasarkan prinsip al-Muhâfazat 'alâ alqadîm al-sâlih wa al-akhdhu bi al-jadîd al-așlah. Gaya kepemimpinan Gus Mad adalah gaya kepemimpinan neo-transformasionalisme, gabungan gaya kepemimpinan transfomasionalisme dan tradisionalisme yang dilandasi prinsip al-muhâfazat 'alâ al-qadîm al-ṣ̂alih wa al-akhdhu bi al-jadîd al-aṣlah.

Keywords: KH. Achmad Zamachsyari; leadership; pesantren modernization

Received: February 17, 2021; Accepted: May 30, 2021

\section{Introduction}

Leadership in an educational institution is one of the most important factors, because it is advanced backward, whether or not the institution develops depends on how a leader manages the institution education. One of the elements of a leader in a Islamic boarding school institution is the existence of a caregiver or kiai (Syafi'i 2019). Kiai is a central figure in the 
boarding school. The progress and withdrawal of the pesantren are also determined by the authority and charisma of a kiai (Daulay 2014). Whether it is a kiai, a person's leadership must be able to design a new organizational management changing to a taklim assembly to achieve agreed goals and development. Various kinds of subordinate characters and the various obstacles that exist, require leaders to think wisely and take advantage of the opportunities or strengths that exist and manage them to achieve predetermined organizational goals (Mathis, Jackson, and Valentine 2011).

KH. Achmad Zamachsyari is a well-known Kiai in Malang with the nickname Gus Mad. He is the second son of the KH. Achmad Rifa'ie Basuni and Nyai $\mathrm{Hj}$. Asmah Shiddiq, founder of the Al-Fattah Islamic Boarding School Singosari Malang. PP Al-Fattah is one of the salafiyah Islamic boarding schools, which until now has maintained its salafi values. During Al-Fattah was led by Gus Mad's father the Islamic boarding school education system applied was the salafiyah education system. After almost 18 years leading Al-Fattah, KH. Rifa'ie finally died in 1977. Gus Mad, then continued his father's leadership at Al-Fattah, although in his heart Gus Mad felt less comfortable because his father and his family rejected the idea of changing the pesantren education system.

At that time, Gus Mad planned to make changes, both in terms of physical development and traditional organizational management into modern ones. However, he did not seem to know the word despair; although he could not change the Al-Fattah Islamic boarding school from salafiyah to modern, he still wanted to apply this thought. Finally, in 1995 he handed over the milestone of Al-Fattah's leadership to his younger brother, Muhammad Ja'far, after he asked his family for permission to leave Singosari and establish a modern Islamic boarding school in another area.

In its development, Islamic boarding schools do not merely grow stagnantly because they are always on the old traditional pattern. Still, innovation can be made in the development of the education system in the boarding school. In its general form of Indonesia, modernization is better known as "development" is a complex multi-dimensional process. Admittedly, the earliest modernization of the education system in Indonesia did not originate from among the Muslims themselves. The emergence of the modernization of Islamic education in Indonesia is closely related to the growth of Islamic modernism in the region. In the field of education, modernization can at least be seen by the realization of the formation of 
modern educational institutions that adopted from the Dutch colonial system and institutions, not from the traditional Islamic education system. (Baharun 2013)

At the beginning of the development of modernism in Islamic education, two main trends underlie the efforts towards the modernization of Islamic organizations. On the one hand, the adoption of modern educational systems and institutions is almost complete. The starting point of Islamic education modernism here is the modern/Dutch educational institutional system, not the traditional Islamic education system and institution. On the other hand, some efforts start from the Islamic education system and the institution itself. Here the Islamic educational institutions that have existed for a long time are being modernized. The pesantren and surau education systems, which are indigenous Islamic education institutions, are updated, for example by taking or imitating certain aspects of the modern education system, especially in the curriculum, techniques and teaching methods, and so on (Azra 1999).

Gus Mad himself became one of the initiators to make changes by building a modern Islamic boarding school in Malang. That initiative then made him a leader, where he had to provide a vision, a direction for others to move on and move from where they started to be towards improvement and change. It is typical for the kiai's position in pesantren to be so central, As well as being an educator and teacher, the kiai is also boarding school managerial holders (Na'im 2013). Gus Mad chose an area in the KetawangGondanglegi-Malang to begin his struggle to build a modern Islamic boarding school. Previously, Gus Mad bought land in the Madura, which is now also a boarding school, but because Gus Mad's mother, Mrs. Nyai Asmah, disagreed, the land was eventually resold.

Indeed, Gus Mad wants to establish a modern Islamic boarding school in Ketawang village, and to build and change the mentality of its residents from backwardness. Gus Mad was sure that the concept of change that he carried out would be successful, although many people were not sure if the modern Islamic boarding school to establish would have many santri. Finally, because Gus Mad's expertise in associating with various levels of society, he obtained a land area of $8,200 \mathrm{~m}^{2}$ which is strategically located on the side of the main road.

Gus Mad's desire to build a modern Islamic boarding school is powerful. It is based on his segmentation of abangan or nationalist people. Still, he wants his sons and daughters to study religion, such as the 
community of Ahl al-Sunnah wa al-Jamâ'ah. Besides, the concept of modernization of pesantren education developed by Gus Mad was not due to the existence of general knowledge taught in the Islamic boarding schools, but rather to the modernized teaching system and physical buildings of the pesantren. With the concept of modernizing pesantren education, Gus Mad hopes to change the students' backwardness and culture with the outside world, without neglecting the ability of students to study religion. Finally, for almost four years, he was able to establish the AlRifa'ie Modern Islamic Boarding School, where the name of the cottage was taken from his own father's, KH. Achmad Rifa'ie Basuni.

Facing the fast changing times, the pesantren world must shift towards more positive developments, both socially and culturally. The shift of pattern concerns leadership, relationship between leaders and students, communication, ways of making decisions and so on. It pays more attention to the principles of scientific management with foundation of Islamic values. The dynamics of this kind of pesantren development feature a dynamic, creative, productive and effective pesantren figure and innovative in every step it offers and develops. Therefore, pesantren is an adaptive and anticipatory institution change and advancement of times and technology without leaving values religious (Hasyim 2016).

Islamic educational institutions can be classified into: (1) traditional Islamic boarding schools (salafiyah), in terms of vision, mission, objectives, curriculum, management, learning methods, and the competence of teachers; (2) modern Islamic boarding schools, namely pesantren with complete management and infrastructure, well planned education, effective teaching methods, and the interests of global education (Nata 2004). On this basis, Gus Mad became one of the kiai's leadership in modernizing the pesantren. The significance of his leadership at PPM Al-Rifa'ie is accompanied by his interaction with his community, both as the founder, caretaker, and leader of the Islamic boarding school. The behavior and interaction patterns shown must be different from one Kiai to another.

Gus Mad is a figure initiator of change in the world of pesantren education. Gus Mad, who was a leader at the Salafiyah Islamic boarding school, decided to resign and build a modern Islamic boarding school. His movements broke the backwardness of society and became a filter in culturing the students with the outside world. Gus Mad, an expert in the field of architecture, later founded a boarding school with a modern building and a comfortable, clean and tidy atmosphere, far from the slum 
impression that has been attached to the Islamic boarding school. His efforts in developing modern Islamic boarding schools are carried out through behaviors and patterns of leadership interactions based on Islamic values in carrying out leadership functions by utilizing his position as a central figure, founder and owner of the pesantren as a whole. It is common for kiai to go through Islamic boarding schools for a tremendous effect (Mustofa 2011); even the pesantren itself claimed as an entity that has a great opportunity to become the center Muslim civilization; including in terms of food security (Pradini 2016).

\section{Method}

This research can be categorized as a qualitative research as it understands the behavior of participants, describes complex settings and interactions, and describes phenomena. In its implementation, this research is carried out using a biography or study approach. The underlying reasons are first, because the researcher focuses on one individual, builds research from stories and special events, then places them in a broader context, and evokes the existence of the researcher in this study (Ghony 2012). Second, because the biographical study of this character is to understand the behavior and patterns of human interaction with their environment through the leadership process (Denzin and Lincoln 1998).

The figure studied in this research is KH. Achmad Zamachsyari, founder of PPM Al-Rifa'ie Malang. The choice of Gus Mad as the figure examined in this study was because Gus Mad had indicators reflecting a character. According to Arief Furchan and Agus Maimun, a person can be considered a figure if he has the indicators successful in his field; hasg monumental works; influences society; and has broad recognition of his personality (Furchan and Maimun 2005).

Using a character study approach, this study uses three data collection methods: interviews, documentation, and observation. Meanwhile, the data analysis method uses Spradley model: (1) domain analysis; (2) taxonomic analysis; (3) component analysis; and (4) cultural theme analysis. First, the researcher took notes on Gus Mad's life. Then she identified the concepts by asking questions about various sides of Gus Mad's life. The researcher then formulated propositions of his leadership style found in modern Islamic boarding schools as well as the concept of modernizing Islamic boarding school education from his perspective. 
The results of interviews, observations, and documentation were analyzed using the Spradley model covering three stages. First, the researcher analyzed the general figure of Gus Mad. Second, she conducted a taxonomic analysis and a comparative analysis seen from his behavior and interaction patterns to find his leadership style in modern Islamic boarding schools. Third, the researcher conducted an cultural theme analysis seen from the form of modernization of Islamic boarding school education as an implication of Gus Mad's leadership.

\section{The Leadership Behavior of KH. Achmad Zamachsyari}

The process of socio-cultural transformation today has almost touched every corner of people's lives. Islamic boarding schools, which are often touted as the oldest educational institutions that maintain traditional values, cannot be separated from this process. However, Islamic boarding schools are able to maintain their existence as a filter of foreign culture so that they can survive in this modern era. The success of the Islamic boarding school in the journey of socio-cultural transformation cannot be separated from the Kiai's leadership role. Kiai became an actor in the effort to develop Islamic boarding school, especially in the effort to create a vision and mission of Islamic boarding schools that are consistent in addition to efforts to develop Islamic education and in the development of santri character education (Hafidh, Zuhri, and Sandi 2019).

The leadership behavior is a series of one's behavior or one's style in implementing leadership functions, which influence and make the organization effective in achieving goals. The need for a good leadership style for kiai in developing the majelis taklim program it carries, a leadership style that does not involve subordinates in making decisions. It will result in disharmony in the relationship between the leader and the one led. Individual leadership in institutions such as majelis taklim for certain interests is needed, but at the same time can also be a weakness of the institution. In carrying out leadership duties, kiais have different characteristics and styles, some are passionate and full of responsibility (Brooks and Muthohar 2018)

Good leadership certainly has an impact on whether or not organizational goals are achieved because leaders have an influence on the performance they lead (Asyari, Hasibuan, and Rosyad 2020). Gus Mad is a figure of Kiai or leader of Islamic boarding schools rarely found in several other Islamic boarding schools. His leadership behavior is quite unique, 
always behaving like an ordinary person who can sit together anytime with his subordinates, not as a boarding school leader or a Kiai who is hard to find. Gus Mad also does not make himself a central figure in holding the authority in the boarding school but rather appreciates all the potential that exists by giving full control regarding the management of the boarding school to his subordinate members. The styles used by a leader are not the same, depending on the situation and condition of the leadership (Klijn, Boer, and Eshuis 2020).

Leadership style becomes the norm of behavior that a person uses when that person tries to influence the behavior of others as well as a consistent pattern of behavior that is demonstrated by the leader and known to other parties when the leader tries to influence the activities of others (Alam 2018). As a leader, Gus Mad has great ideas in developing PPM Al-Rifa'ie. His big ideas are not only oriented for a period of one or two years to come, but the existence of Islamic boarding schools for decades to come. Gus Mad has surveyed in advance the community's needs and the market segmentation formed. From the survey results, he saw that Malang community wanted their children to be able to study religion without neglecting general knowledge in a balanced degree.

Therefore, one of Gus Mad's big ideas is to modernize pesantren education, and his goal for PPM Al-Rifa'ie is "to make al-Rifa'ie not everywhere but everywhere". The modernization of pesantren education referred to changing the salafiyah teaching system, making religious and general curricula, and providing complete and modern Islamic boarding school facilities. Besides, students are also equipped with foreign language skills (Arabic and English) as well as provision of life skills for social life. In leading PPM Al-Rifa'ie, Gus Mad conveys his vision, mission, and aspirations to all his subordinates, provides direction and motivation for its implementation and gives solutions of any problems.

The result of interviews shows that Gus Mad, as the head of the Islamic boarding school, has characteristics that can articulate a vision and has the ability and actions that prioritize common interests over personal interests. Such behavior makes Gus Mad a charismatic leader in the eyes of his subordinates, which is represented through the form of obedience, discipline, enthusiasm, and commitment of the assistants to manage PPM Al-Rifa'ie. The behavior that reflects a democratic and visionary attitude makes Gus Mad a charismatic leader not because he is a Kiai, but because of his authoritarian personality. 
Usually, leaders have their own way of carrying out their leadership, their way or style of thinking is different from one another, they have their own way of carrying out their leadership duties in order to achieve predetermined organizational goals. It affects the success of achieving the organizational goals he dreams of (Hammad 2019). Therefore, a leader always strives to carry out his duties optimally, one of which is by innovating to create new things to develop his organization (Hasan 2019).

The situation kiai builds is centralistic leadership pattern in nurturing and managing the pesantren. The position of the kiai is very strong and determines what is identified as the individual leadership of the kiai and feudal charismatics (Davies 2016). However, being a charismatic leader does not make Gus Mad then just keep quiet, he also acts by motivating and inspiring his subordinates directly or indirectly by teaching the principle of talk less do more. Although basically Gus Mad gives full authority to the people under him to achieve the vision of the Islamic boarding school, it does not mean that he would just let go. In this case, Gus Mad always encourages and inspires his subordinates to carry out their service tasks creatively and innovatively.

His being disciplined in respecting time, diligent in working and cares for the conditions of his associates, made Gus Mad a source of inspiration, motivation, and strength for the board of boarding schools. Sincere dedication is one of the personifications of the deputies to Gus Mad, who shows a sense of sincerity in managing PPM Al-Rifa'ie. As a leader, Gus Mad encouraged all to understand the vision, mission, and ideals of the Islamic boarding school by granting the authority to manage the boarding school as a whole. It can be said to be the process of regeneration he carried out in preparing leaders who have equal abilities with him.

The finding shows that in leading PPM Al-Rifa'ie: first, Gus Mad was able to make himself an ideal leader in the eyes of his subordinates through his charisma. It can be seen from his scientific point of view in both natural and supernatural sciences. Second, as a leader, Gus Mad has a big idea, namely to modernize Islamic boarding school education, which is driven by strong belief to make it happen, as well as commitment and consistency in the implementation process. Third, the community highly recognizes Kiai's charisma because he is seen as having strengths, moral stability and spiritual intelligence which gives birth to a personality model, so that he can become a magnet for his followers (Susanto 2017). However, the charisma of a kiai 
is not sufficient if only used in transformational leadership; because it affects the whole circumstances including the emotional aspect of the followers (Ayiro 2014).

As a boarding school leader, Gus Mad is good at motivating and inspiring his subordinate members to have high enthusiasm in developing Islamic boarding schools. Some of the strategies he implemented are: (1) making himself a good uswatun hasanah or a role model for his subordinates; (2) providing rewards for subordinate members who do a good job; (3) always holding muhâsabah or self-evaluation every month in order to change and improve and it becomes one of his communication media with all members of his subordinates. Robbins (2015) states that, "transformational leadership is leadership that inspires his followers to go beyond their self-interest, which is capable of bringing tremendous impact on his followers". Leadership style transformational that is applied will foster trust for followers, which is the capital for the growth and development of sharing knowledge (Helmi and Arisudana, 2015). Pesantren leaders that inspires and motivates as a part of transformational leadership is more effective than only performing the charisma of the kiai in carrying out the governance of pesantren institutions (Indrawati 2014).

Although Gus Mad was the founder and owner of PPM Al-Rifa'ie, he did not make himself a single authoritarian leader towards his subordinates. On the contrary, he wanted a democratic organizational atmosphere, so that he gave his authority to all subordinate members by delegating tasks. It is done as a stimulus for his subordinates to be able to develop their potential freely in order to achieve the vision and mission of the Islamic boarding school.

As a leader and also a Kiai, Gus Mad is able to pay attention to his subordinates both individually and collectively. Individually, it was done by Gus Mad through one-on-one discussions and exchanging ideas regarding matters of Islamic boarding schools and personal matters. Meanwhile, to pay attention to all members of his subordinates, Gus Mad always held a meeting at his residence at the end of every month and held events that involved them.

Gus Mad's leadership behavior at PPM Al-Rifa'ie was transformational leadership. It refers to the process of building commitment to organizational goals and giving the followers confidence to achieve those goals. Transformational leaders seek to transform from visionary into a shared vision (leader and subordinates). In other words, transformational 
leadership is seen through a number of leadership behaviors such as: idealized influence, inspirational motivation, intellectual stimulation and individualized consideration (Yukl 1999).

Transformational educational leaders are characterized by the leader's ability to answer various challenges, maintain a vision of a good school and achieve it with high energy and commitment, and demonstrate personal qualities that refer to moral integrity (Coulson 1990). Meanwhile, according to Burns, transformational leadership is a process where leaders and followers raise each other to a higher level of morality and motivation. In relation to Maslow's level of needs, transformational leaders need to increase the needs of subordinates from the most basic level to the top level, namely self-actualization (Burns 1978).

Gus Mad's transformational leadership can foster enthusiasm in subordinate members to achieve the vision and mission of the Islamic boarding school. In transformational leadership the orientation is to increase the commitment of subordinates to the achievement of the objectives of the Islamic boarding school. Kiai's transformational leadership can invite his subordinates to do more tasks for the sake of achieving larger organizational goals (Podungge 2018). With the application of a transformational leadership style, the members will do their job optimally because the assignment of a leader is not a heavy burden. Leaders can influence their members so that when given a task, the members will happily accept (Senny, Wijayaningsih, and Kurniawan 2018). With transformational leadership then subordinates will feel trusted, valued and appreciate the leader more.

From the discussion and description above related to the leadership behavior of kiai in Islamic boarding schools, the following propositions can be formulated: Having charisma, being a motivator and an inspirational figure, creating a democratic organizational atmosphere by delegating tasks, and caring for his subordinates are Gus Mad leadership behavior at PPM Al-Rifa'ie which leads to a transformational leadership style.

\section{The Interaction Pattern of KH. Achmad Zamachsyari}

Kiai is the main component of communication in Islamic boarding schools. Kiai is not only as actors of communication but also as context, figure, or patron of how Islamic boarding school community, especially students and ustâdh communicate. Presence and activeness of the Kiai in the Islamic boarding school give a significant effect. Kiai is also the main 
communicator, the source communicator of the main science (Nasvian, Prasetyo, and Wisadirana 2013). Leadership itself involves two or more people in interacting. The process of individual interaction can influence other individuals to think and behave in their own way which will be the second key point in influencing leadership (Susanto 2014). Leadership involves a deep relationship of influence that occurs between people who want significant change, this change reflects a shared goal by the leader and his followers. Influence in this case means the relationship between the leader and followers so that it is not something passive, but is a relationship that is reciprocal and without coercion (Fauzi 2017).

Kiai as the highest leader in the boarding school, has his own uniqueness in leadership system. The term Kiai in context Indonesian, does not only mean a figure or individual who is expert in the field of religion, but more than that. If viewed from an anthropological meaning, Kiai is an individual who has advantages and is capable of everything level of life problems, as well as social control. Kiai is a figure filled with an extremely high charismatic aura, as well occupy a great position (high class) in the social strata, especially for the ummah Islam. So it is not surprising that everything said by the Kiai is believed by the people (sami'nâ wa ata'nâ) (Bashori 2019).

As a founder, caretaker, and leader of PPM Al-Rifa'ie, Gus Mad actively interacts with the internal community (students and administrators) and external community of the boarding school at every opportunity. The pattern referred to here is how it works or form communication carried out by the kiai. Interaction is a process where people communicate influence each other in mind and action. The interaction pattern is a form of reciprocal relationship between one person and another. As social beings, the human tendency to relate to others gives birth two-way communication, either through language or deeds. The action and the reaction occurring belong to the element that forms the occurrence of interaction (Suhartina 2020).

One of the skills of Gus Mad is being able to interact with all levels of society, including bureaucratic officials, academics, religious leaders and ordinary people. His ability to interact makes PPM Al-Rifa'ie proliferate and is widely recognized by all people. In this case, Gus Mad describes it as a take and give concept where when someone needs his help both from a scientific perspective and in material form, that person will indirectly assist the boarding school. 
First, Gus Mad's interactions with students and the board were wellpatterned. His attitude of tawaddu or humble represents respect and admiration for someone who has specific features. The belief in the existence of 'barokah' that is contained in the figure of Gus Mad, makes the students and administrators feel flattered and a kind of self-appreciation with the high intensity of interactions carried out by Gus Mad. This belief will form a person who is loyal to the institution and tries to follow all the words, actions, appearances, and other things done by the Kiai. Gus Mad is not only a teacher but also a father figure to his children who should be emulated and made a role model. In this case, Gus Mad engages in physical interaction, he always presents himself in the midst of the students at every event, and provides opportunities for 24-hour educational - democratic interactions.

In most of the interaction with his students, Gus Mad gave more motivation through the maw'izah hasanah or wise words for them to always be enthusiastic in seeking knowledge at the Islamic boarding school. In addition, Gus Mad also uses the exemplary motivational approach (uswah), for example he gives an example to his students by always praying five times in congregation in istiqâmah (continual). The close interaction between the kiai and the students shows that the kiai as a caretaker of the Islamic boarding school provides opportunities for educational intensification. The process of interaction and communication that occurs in learning and teaching activities also involves a forum of small group activity. Besides, the communication between kiai and students in the class can be an interpersonal communication by using a two-way communication method or dialogue, namely kiai being communicators and students become communicants (Ramdan and Usman 2021).

Second, as a boarding school leader, Gus Mad has a big mandate in managing the pesantren. However, it does not mean that Gus Mad is the only person who determines the direction of policy and development of Islamic boarding schools. Almost all of the management at PPM Al-Rifa'ie are controlled by the administrators/subordinate members (teachers/ asâtidh/staff). There is also a pattern of interaction between kiai and their subordinates in managing the boarding school related to both institutional and non-institutional affairs. Gus Mad carried out the interaction pattern to show intimacy while maintaining his authority as the leader of the Islamic boarding school. 
The interview results show that in interacting with his subordinates, Gus Mad prefers mindset interactions where Gus Mad often invites his subordinates to share and discuss the management of the boarding school. Even though he is the head of the Islamic boarding school, Gus Mad does not hesitate to accept input ideas or suggestions from his subordinates. Apart from that, he also routinely meets with his subordinates. Once a month for muhâsabah in the form of mutual istighâthah. Gus Mad did this because he wanted to meet face to face with all members of his subordinates, even though in his daily life, he also tried to greet them directly.

Third, in addition to interacting with the internal community of the boarding school, Gus Mad also interacts with the external community of the boarding school. The interaction of the spirit that was carried out by Gus Mad with the community through spiritual activities such as, joint prayer, prayer, and other religious events was one of the Kiai's media to interact with the community. Considering that the people of Ketawang village in particular are known for their backwardness, both from an economic perspective and an understanding of religion, Gus Mad is here to carry out social change by giving a strong influence in the midst of society. The depth of religious knowledge that is balanced with a populist lifestyle, as well as high charisma and always providing assistance to people in need, make the community support the spiritual activities held by Gus Mad.

The finding also shows that the patterns of interaction were more of a spiritual one, such as istighathah and praying together apart from being used to praying and having dhikr together. These activities seemslike a medium for communication between Gus Mad and the outside community. Gus Mad also interacts with the community through socio-religious activities, as exemplified by the Prophet Muhammad PBUH. The intensity of Gus Mad's interactions with the community appears from the number of guests who come and go in and out of his house almost every day to invite him to attend an event or just ask for advice/prayers from Gus Mad. From the way Gus Mad interacts with the community, at least there will be a pro and contra response to his attitude. The higher a person's degree, the bigger the storm that will hit him. However, it did not make Gus Mad close himself to the outside community. But in general, there were more who responded well to Gus Mad's attitude in interacting with the community. It is evident by the increasing number of the congregations every year, even the assembly 
is not only for Ketawang villagers or around Malang, but also people outside the city.

It is in line with what Horikhoshi expressed, that kiai have a creative role in social change, namely introducing elements of the external system and causing change in society. Social changes that occur in Islamic boarding schools which then have a positive impact on society are caused by the role of kiai actors. This process of change can be observed in the roles of Islamic boarding schools in carrying religious messages framed by the existing value system in society, such as mutual help, politeness, enthusiasm for life in doing business and work and even inviting them to open up to new things in society like technology and globalization (Horikoshi 1987).

The interaction between leaders and subordinates is an important part of any organization, including organizations in Islamic boarding schools. Even though the head of the boarding school is a Kiai, it does not mean that he has to close himself off to his subordinates, on the contrary the Kiai must frequently interact not only with the internal community of the boarding school, but also with the external community of the boarding school. This is in line with the interaction theory which in principle is the same as Fiedler's contingency theory and Stogdill's expectancyreinforcement theory. Where this interaction theory assumes that the more frequent interaction and participation in joint activities, the greater the feeling of liking one another and clarifying mutual understanding of group norms (Saefullah 2012).

The physical interactions made by Gus Mad towards the students will bring out the tawaddu attitude of the students towards the kiai and give rise to the term "ngalap barokah". The students will obey whatever is said and ordered by Gus Mad in order to expect the blessings of the knowledge they learn at the Islamic boarding school. Meanwhile, Gus Mad's mindset interactions with his subordinate members, as well as the spiritual interactions he does to the community will bring out high obedience, loyalty and obedience from subordinate members and society towards Kiai and Islamic boarding schools. This is in line with the traditional leadership style in which obedience is given to people or leaders who occupy traditional power who are also bound in this atmosphere (Weber 1978). Followers obedient to leadership is not based on impersonal order, but becomes personal loyalty within the scope by accustoming submission to obligations. 
From the discussion above regarding the interaction of the kiai with the internal and external communities of the boarding school, the following propositions were formulated: The interactions made by Gus Mad with the internal and external communities of PPM Al-Rifa'ie through interaction patterns of Physical interactions (al-mu'âmalah al-jismiyah), mindset interactions (al-mu'âmalah al-fikriyah), and spirit interactions (al-mu'âmalah alrûhiyah) lead to attitudes of obedience, loyalty and obedience high level, thus leading to a traditional leadership style.

\section{Implications of KH. Achmad Zamachsyari's Leadership in Modernization of Pesantren}

Hearing the term Islamic boarding school, anyone who has ever come into contact with their reality will be carried into a dynamic, religious, scientific and exotic nuance of life. It is also possible that the term Islamic boarding school will lead to the shadow of a place that demands orthodox, static, closed, and traditional religion. Islamic boarding schools as the oldest institution in Indonesia always preserve the values of traditional teachingbased education. The preservation of the traditional system and methodology makes it a traditional Islamic boarding school (Muhakamurrohman 2014).

The modernization of pesantren is still seen as a formality which tends to add to formal institutions only. However the current pesantren looks good although there is still a lot to be improved in the future. Pesantren reform is a necessity that must be done by the authority of the pesantren so that it remains a place providing solutions to the various problems of modern human life (Mukaffan and Siswanto 2019). It should be recognized that the renewal or modernization of the system education in Indonesia does not come purely from the circle of Indonesian Muslims themselves. Karel Steenbrink, mentions several factors of the reform of Islamic education in Indonesia at the beginning of the 20th century. Since 1900, there have been many rethinking on the Quran and Sunnah which were made starting point for assessing existing religious and cultural customs (Steenbrink 1986).

Modernizing the pesantren starts from modernization of Islamic education which has roots in the notion of the modernization of thought and Islam institutions as a whole, namely the modernization of thought and Islamic institutions which are a prerequisite for the rise of the Muslims in modern times. Therefore, Islamic institutional thinking must be 
modernized according to the framework of modernity (Bashori 2017). The pesantren has undergone a very significant change because of this the ongoing modernization of pesantren in Java since the New Order era. In these changes, pesantren now has four types of education namely education that concentrates on tafaqquh fî al-din, madrasah-based education, general school-based education and skills-based education. The modernization of pesantren has changed the system and pesantren education institutions. Very basic change for example, it occurs in certain aspects of the institution (Setiawan 2013).

Islamic boarding school as an Islamic educational institution, in its journey, cannot escape the influence of modernization, especially with the times that are accompanied by advances in science and technology. This condition motivates Gus Mad to make changes in the management of education, namely the modernization of pesantren education. The leadership innovation shown by Gus Mad in the context of modernizing pesantren education has had a positive impact on its education system, from the teaching system, the curriculum to the provision of facilities and infrastructure. In leading PPM Al-Rifa'ie Gus Mad always holds the principle of al-muhâfazat 'alâ al-qadîm al-șâlih wa al-akhdhu bi al-jadîd al-aṣlaḥ.

First, in terms of curriculum, it was found that Gus Mad organized religious education in the form of madrasah diniyyah and also organized formal education by applying the national curriculum through public schools such as junior high schools, high schools and vocational schools. In addition, Gus Mad also created an additional curriculum to cultivate foreign language intelligence and also provide life skills in the form of extracurricular activities. In this case, he really wants to provide a balanced portion between general science and religious knowledge so that there is no dichotomy of knowledge in Islamic boarding schools and to equip students with soft skills to support their future life in society.

For the curriculum in each educational unit at PPM Al-Rifa'ie, in addition to the general school curriculum that follows government standards, Gus Mad's diniyyah school combines its curriculum with the Lirboyo Islamic boarding school curriculum. As for the Quran learning curriculum, it is now using the tajdîdah curriculum. The curriculum for intelligence cultivation of foreign language skills (Arabic and English) and provision of life skills are through extracurricular activities. From the observations, even though PPM Al-Rifa'ie teaches general knowledge to the students, it also maintains the teaching of classical Islamic books such as in 
the salafiyah Islamic boarding school as an effort to balance matters of the world and the hereafter. The integration between general knowledge and religion is make students understand that the term dichotomy of expertise does not exist in Islam.

The reform of the curriculum aspects has been started by the pesantren since Dutch times, especially in the 1920s, albeit on a scale which is very limited. The reform of the pesantren was not running evenly in all pesantren; some pesantrens that accept curriculum reforms are still cautious limit oneself to some aspects of the material, teaching system, and teaching time. At that time, even more pesantrens who reject the curriculum reform or the substance of pesantren education, especially because the offer came from the Dutch colonial government (Basyit 2017).

Second, the teaching systems/methods no longer use a conservative teaching systems such as sorogan, bandongan, or wetonan, but Gus Mad balances with a modern teaching system, namely a class/grading system like a public/formal school. PPM Al-Rifa'ie held double education with a full day school teaching system oriented towards mastering science and technology (IPTEK) and IMTAQ. Meanwhile, the learning method used was also modified. Gus Mad did not want the learning method used to be textual only but must also be contextual. The teacher/asâtidh does not only give lectures in delivering lessons but also practice directly or provide opportunities for students to have discussions such as in bahtsul masail activities.

Gus Mad has changed the teaching system in the Salafiyah Islamic boarding school known as sorogan and wetonan to Double Education, which is packaged in the Full Day School system, which is oriented towards mastery of science and technology (IPTEK) and IMTAQ. So, in managing education and teaching at PPM Al-Rifa'ie, Gus Mad changed the conservative teaching system to be more systematic with the concept of full day school. Apart from that, Gus Mad also wanted the teaching method used to be textual and contextual. In teaching and learning activities, the teachers/asâtidh were not allowed only to use the lecture method.

Third, the facilities and infrastructure at PPM Al-Rifa'ie stand out prominently in showing its image as a modern Islamic boarding school. All the buildings in the boarding school are the work of architect Gus Mad himself, for the dormitory and school buildings are all made like flat buildings with three levels. In addition, complete learning facilities in 
accordance with respective scientific competences are also made modern, as well as a clean, quiet and comfortable learning atmosphere. Al-Rifa'ie Middle School building consists of 17 classrooms divided into three floors. Al-Rifa'ie High School building consists of 16 classrooms divided into four floors Al-Rifa'ie Vocational High School building currently there are still eight classrooms on one floor. $\mathrm{Up}$ to three floors are still under construction.

The characteristics of the appearance of physical buildings at PPM AlRifa'ie are basically in accordance with the results of Becker's research which shows that educational institutions that emit a beacon of brilliantness are educational institutions that have adequate buildings and learning equipment for students, and not as a school that is ravaged by disease (potholes of pestilence), which has dirty, unkempt buildings, an unsanitary environment for children's learning and growth, and a school that lacks staff and equipment (Becker 1971). Therefore, the modernization of facilities and infrastructure carried out by Gus Mad in order to eliminate negative public perceptions of Islamic boarding schools. So the impact of Gus Mad's leadership is that PPM Al-Rifa'ie is considered a modern Islamic boarding school that is advanced and developing as evidenced by the relatively rapid increase in the number of santri.

Various kinds of things done by Gus Mad for Islamic boarding schools in response to modernization are in accordance with what Azyumardi Azra said, namely: First, renewing the substance or content of pesantren education by including general subjects and skills (vocational). Second, updating the methodology, such as classical systems and tiering. Third, institutional reforms such as boarding school leadership, diversification of educational institutions. And fourth, renewal of functions, from educational functions to also include socio-economic functions (Azra 1999). Modernization of Islamic education in the development of implementation contemporary education does not only change the basis of socio-cultural and knowledge of the santri elite, but also affects the Muslim community whole. The santri and ulama elite who originally grew and developed deeply pesantren education system, is now growing, developing, and matured by modern education system through other Islamic social media (Hasyim 2018).

The implication of Gus Mad's leadership in the modernization of innovative pesantren is to respond to advances in science and technology, making PPM Al-Rifa'ie have complete and modern facilities and 
infrastructure. This condition actually made PPM Al-Rifa'ie able to develop rapidly at a relatively young age. Because today's parents want their children to be able to recite the Holy Quran but also not be tech-savvy like other children who are in public schools. So, the concept of modernization of Islamic boarding school education with the perspective of Gus Mad using the principle of al-muhâfazat 'alâ al-qadîm al-șâlih wa al-akhdhu bi al-jadîd alaslah is seen in three aspects, namely: curriculum, teaching systems and methods, and facilities and infrastructure. The provision of complete and modern facilities as well as the development of foreign language skills (Arabic and English) is one of the prominent characteristics of PPM AlRifa'ie. The findings of this study is summarized in table 1 .

Table 1

Research Result

\begin{tabular}{|c|c|c|c|}
\hline No & $\begin{array}{c}\text { The Leadership } \\
\text { Behavior of KH. } \\
\text { Achmad Zamachsyari }\end{array}$ & $\begin{array}{c}\text { The Interaction } \\
\text { Pattern of KH. } \\
\text { Achmad Zamachsyari }\end{array}$ & $\begin{array}{c}\text { The Leadership } \\
\text { Implications of KH. } \\
\text { Achmad Zamachsyari in } \\
\text { Pesantren Modernization }\end{array}$ \\
\hline 1 & $\begin{array}{l}\text { Making changes by } \\
\text { building a modern } \\
\text { Islamic boarding } \\
\text { school in the city of } \\
\text { Malang, changing the } \\
\text { lives of the backward } \\
\text { Ketawang community }\end{array}$ & $\begin{array}{l}\text { Kiai - Santri: } \\
\text { Relationship between } \\
\text { parents and children, } \\
\text { they often interact } \\
\text { directly by presenting } \\
\text { themselves in the } \\
\text { midst of the students } \\
\text { through book } \\
\text { recitation activities, } \\
\text { priests praying in } \\
\text { congregations, giving } \\
\text { maw'izah hasanah at } \\
\text { every student activity, } \\
\text { etc. which can create } \\
\text { tawaddu and the term } \\
\text { "ngalap barakah" in } \\
\text { students. }\end{array}$ & $\begin{array}{l}\text { Managing and developing } \\
\text { modern Islamic boarding } \\
\text { schools with the principle } \\
\text { of "al-Muhâfazat "alâ al- } \\
\text { qadîm al-sâlih wa al-akhdhu } \\
\text { bi al-jadîd al-aṣlah" which } \\
\text { covers three aspects: } \\
\text { curriculum, teaching } \\
\text { systems and methods and } \\
\text { facilities, and } \\
\text { infrastructure }\end{array}$ \\
\hline 2 & $\begin{array}{l}\text { Having a personality } \\
\text { that can attract the } \\
\text { attention of many } \\
\text { people because of the }\end{array}$ & $\begin{array}{l}\text { Kiai - Teacher / } \\
\text { Ustâdh } \\
\text { for those who are } \\
\text { managerial }\end{array}$ & $\begin{array}{l}\text { The curriculum consists } \\
\text { of four categories: Formal, } \\
\text { Diniyah, Quran, and } \\
\text { Extracurricular Learning. }\end{array}$ \\
\hline
\end{tabular}




\begin{tabular}{|c|c|c|c|}
\hline & $\begin{array}{l}\text { advantages of his } \\
\text { knowledge, behaving } \\
\text { like an ordinary } \\
\text { person who can sit } \\
\text { together with anyone } \\
\text { and at any time, } \\
\text { prioritizing common } \\
\text { interests over personal } \\
\text { interests }\end{array}$ & $\begin{array}{l}\text { (institutional affairs) } \\
\text { more often interact } \\
\text { through sharing, one- } \\
\text { on-one discussions, } \\
\text { and also asking for } \\
\text { input for } \\
\text { ideas/suggestions } \\
\text { which will lead to } \\
\text { obedience, loyalty, } \\
\text { and obedience } \\
\text { (loyalty) of } \\
\text { subordinate members } \\
\text { who high towards Kiai } \\
\text { and Islamic boarding } \\
\text { schools. }\end{array}$ & $\begin{array}{l}\text { Providing foreign } \\
\text { language skills (Arabic } \\
\text { and English) is one of the } \\
\text { main curricula. }\end{array}$ \\
\hline 3 & $\begin{array}{l}\text { Always provide } \\
\text { motivation and } \\
\text { direction to their } \\
\text { subordinates, give } \\
\text { rewards to } \\
\text { subordinate members } \\
\text { who work seriously }\end{array}$ & $\begin{array}{l}\text { Kiai - Society: } \\
\text { The interaction is } \\
\text { through socio- } \\
\text { religious activities, } \\
\text { whether carried out by } \\
\text { Islamic boarding } \\
\text { schools such as } \\
\text { istighâthah and hajat } \\
\text { prayers or by the } \\
\text { community such as } \\
\text { inviting lectures, tahlîl, } \\
\text { etc. }\end{array}$ & $\begin{array}{l}\text { The teaching system is } \\
\text { made in the form of a } \\
\text { class system with the } \\
\text { concept of Full Day } \\
\text { School by integrating } \\
\text { science and technology } \\
\text { (IPTEK) and IMTAQ. } \\
\text { The learning method is } \\
\text { combined through } \\
\text { available media using a } \\
\text { contextual approach }\end{array}$ \\
\hline 4 & $\begin{array}{l}\text { Having a clear vision } \\
\text { and mission, long- } \\
\text { term oriented big } \\
\text { ideas, discipline, } \\
\text { perseverance, and } \\
\text { responsibility at work } \\
\text { as uswatun hasanah or } \\
\text { role model for his } \\
\text { subordinates }\end{array}$ & & $\begin{array}{l}\text { The most prominent } \\
\text { facilities and } \\
\text { infrastructure are school } \\
\text { buildings and dormitories } \\
\text { such as flat buildings. } \\
\text { Facilities are made as } \\
\text { complete and modern as } \\
\text { possible, both to support } \\
\text { the learning activities of } \\
\text { the students and to } \\
\text { support the } \\
\text { accommodation/daily } \\
\text { needs of the students. }\end{array}$ \\
\hline
\end{tabular}




\begin{tabular}{|l|l|l|l|}
\hline 5 & $\begin{array}{l}\text { Appreciate the } \\
\text { potential of } \\
\text { subordinates by } \\
\text { delegating tasks, } \\
\text { providing } \\
\text { opportunities for } \\
\text { subordinates to } \\
\text { develop, making } \\
\text { decisions/policies } \\
\text { through deliberation } \\
\text { processes }\end{array}$ & & \\
\hline
\end{tabular}

\section{Conclusion}

The leadership behavior of $\mathrm{KH}$. Achmad Zamachsyari at PPM AlRifa'ie can be categorized as follows: (a) Charismatic; (b) Inspirator; (c) Motivator; and (d) Democratic. Gus Mad's leadership behavior leads to a transformational leadership style. The interaction patterns of KH. Achmad Zamachsyari with students, ustadz/ustadzah and the community around PPM Al-Rifa'ie through active interactions, including: (a) Physical interaction (al-mu'âmalah al-jismiyah); (b) Interaction of thought patterns (almu'âmalah al-al-fikriyah); and (c) The interaction of the spirit (al-mu'âmalah alrûhiyah) which gives rise to attitudes of obedience, loyalty and high obedience (loyalty) leading to a traditional leadership style. Leadership implications of KH. Achmad Zamachsyari at PPM Al-Rifa'ie cover three aspects, namely: (a) Teaching System; (b) Curriculum; and (c) Facilities and Infrastructure by using the principle of al-muhâfazat 'alâ al-qadîm al-ṣâlih wa al-akhdhu bi al-jadîd al-aslah.

The findings show that the leadership style of KH. Achmad Zamachsyari at PPM Al-Rifa'ie Malang is a Neo-Transformationalism Leadership Style. Neo-Transformationalism leadership style is a combination of transformationalism leadership style and traditionalism leadership style which is based on the principles of al-muhâfazat 'alâ al-qadîm al-sâlih wa alakhdhu bi al-jadîd al-aslah.

\section{References}

Alam, Naufal Ahmad Rijalul. 2018. "Strengthening Leadership Culture (The Role of Kiai in Indonesian Pesantren)." At-Ta'dib: Journal of Pesantren Education 13(1): 5-17. 
DOI: http://dx.doi.org/10.21111/at-tadib.v13i1.1986.

Helmi, Avin Fadilla, and Imam Arisudana. 2015. "Kepemimpinan Transformasional, Kepercayaan dan Berbagi Pengetahuan dalam Organisasi." Jurnal Psikologi 36(2): 95-105. DOI: http://dx.doi.org/10.22146/jpsi.7888

Asyari, Hasyim, Abdul Aziz Hasibuan, and M. Nabilur Rosyad. 2020. "Kepemimpinan Karismatik KH. Moh. Hasib Wahab di Pondok Pesantren Bahrul Ulum Tambakberas Jombang." Nidhomul Haq: Jurnal Manajemen Pendidikan Islam 5(2): 247-61.

DOI: https://doi.org/10.31538/ndh.v5i2.649

Ayiro, Laban P. 2014. "Transformational Leadership and School Outcomes in Kenya: Does Emotional Intelligence Matter?” FIRE: Forum for International Research in Education 1(1): 26-49.

DOI: https://doi.org/10.18275/fire201401011011

Azra, Azyumardi. 1999. Pendidikan Islam: Tradisi dan Modernisasi Menuju Millenium Baru. Jakarta: Logos.

Baharun, Hasan. 2013. Transformasi Kelembagaan Pendidikan Pondok Pesantren. Retrieved from NU Online: https://www.nu.or.id/post/read/44962/transformasi-kelembagaanpendidikan-pondokpesantren (June 06, 2013).

Bashori, Bashori. 2017. "Modernisasi Lembaga Pendidikan Pesantren Perspektif Azyumardi Azra." Nadwa: Jurnal Pendidikan Islam 11(2): 269-96.

DOI: https://doi.org/ 10.21580/nw.2017.11.2.1881

Bashori, Bashori. 2019. "Kepemimpinan Transformasional Kiai Pada Lembaga Pendidikan Islam.” Al-Tanzim: Jurnal Manajemen Pendidikan Islam 3(2): 73-84.

DOI: https://doi.org/10.33650/al-tanzim.v3i2.535

Becker, Marshall H. 1971. "Sociometric Location and Innovativeness; Reformulation and Extension of the Extention of the Diffusion Model." American Sociological Review 35(2): 267-304. 
Brooks, Melanie C. and Agus Muthohar. 2018. "Islamic School Leadership: A Conceptual Framework." Journal of Educational Administration and History 50(2): 54-68.

DOI: https://doi.org/10.1080/00220620.2018.1426558

Burns, James M. 1978. Leadership . New York: Harper \& Row.

Coulson, A. 1990. "Primary School Headship: A Revies of Research.” In R. \&. Saran, Research in Education Management and Policy. London: The Falmer Press.

Daulay, Haidar Putra. 2014. Pendidikan Islam dalam Perspektif Filsafat. Jakarta: Kencana Prenada Media Group.

Davies, Sharyn Graham. 2016. "Gender and powe in Indonesian Islam: Leaders, feminists, Sufis and pesantren selves.” Theology $\mathcal{E}$ Sexuality 22(1-2): $128-30$.

DOI: https://doi.org/10.1080/13558358.2017.1296699

Denzin, Norman K., and Yvonna S. Lincoln. 1998. Handbook of Qualitative Research. New Delhi: Sage.

Fauzi, Ahmad. 2017. "Kepemimpinan Kepala Madrasah Dalam Mengembangkan Lembaga Pendidikan Islam.” Nidhomul Haq: Jurnal Manajemen Pendidikan Islam 2(2): 42-53.

DOI: https://doi.org/10.31538/ndh.v2i2.22

Furchan, Arief and Agus Maimun. 2005. Studi Tokoh: Metode Penelitian Mengenai Tokoh. Yogyakarta: Pustaka Pelajar.

Ghony, Muhammad Djunaidi. 2012. Metode Penelitian Kualitatif. Yogyakarta: Ar-Ruzz Media.

Hafidh, Zaini, M. Tajuddin Zuhri, and Wawan Kurniawan Sandi. 2019. "The role of Kiai leadership and character education: a pattern of Santri character." Journal of Leadership in Organizations 1(2): 134-45.

DOI: https://doi.org/10.22146/jlo.45618

Hammad, Hallinger. 2019. "Knowledge production on educational leadership and management in Arab societies: A systematic review of research." Educational Management Administration $\mathcal{E}$ Leadership 47(1): $20-36$.

DOI: https://doi.org/10.1177/1741143217717280 
Hasan, Hakim. 2019. "Inovasi Kurikulum Pendidikan SMA Darul Ulum 2 di Pondok Pesantren Darul Ulum Jombang." Jurnal Manajemen Pendidikan Islam Al-Idarah 4(2): 1-13.

Hasyim, Muhammad. 2016. "Modernisasi Pendidikan Pesantren Dalam Perspektif KH. Abdurrahman Wahid.” Cendekia: Jurnal Studi Keislaman 2(2): 168-92.

DOI: https://doi.org/10.37348/cendekia.v2i2.27.

Horikoshi, Hiroko. 1987. Kiai dan Perubahan Sosial. Jakarta: P2M.

Indrawati, Nur Khusniyah. 2014. "Management by Inspiration: Implementation of Transformational Leadership on Business at Pondok Pesantren." Procedia - Social and Behavioral Sciences 115: 7990.

DOI: https://doi.org/10.1016/j.sbspro.2014.02.417

Klijn, Eric Hans, Noortje de Boer, and Jasper Eshuis. 2020. "Leading frontline enforcers: How supervisors' leadership style impacts inspectors' enforcement style.” Public Management Review: 1-20.

DOI: https://doi.org/10.1080/14719037.2020.1833610

Mathis, Robert L., John H. Jackson, and Sean R. Valentine. 2011. Human Resource Management: Essential Perspective. Cengage Learning.

Muhakamurrohman, Ahmad. 2014. "Pesantren: Santri, Kiai dan Tradisi". Ibda: Jurnal Kebudayaan Islam 12(2): 109-118.

DOI: https://doi.org/10.24090/ibda.v12i2.440

Mukaffan, Mukaffan and Ali Hasan Siswanto. 2019. "Modernisasi Pesantren Dalam Konstruksi Nurcholish Madjid.” Cendekia 17(2): 285-300.

DOI: https://doi.org/10.21154/cendekia.v17i2.1719

Mustofa, Imam. 2011. "Menjadikan Pesantren Sebagai Pusat Peradaban Muslim di Indonesia." Millah: Jurnal Studi Agama 11(1): 78-108.

DOI: https://doi.org/10.20885/millah.vol11.iss1.art4

Na'im, Ngainun. 2013. "Pesantren dan Pembentukan Manusia Karakter." Al-Ifkar: Journal for Islamic Studies 1(1): 1-21.

Nasvian, Moch. Fuad, Bambang Dwi Prasetyo, and Darsono Wisadirana. 2013. "Model Komunikasi Kiai dengan Santri (Studi Fenomenologi 
Pada Pondok Pesantren "Ribathi" Miftahul Ulum)." Wacana: Jurnal Sosial Humaniora 16(4): 197-206.

Nata, Abudin. 2004. Tokoh-tokoh Pembaharuan Pendidikan Islam di Indonesia. Jakarta: Raja Grafindo Persada.

Podungge, Abdul Wahab. 2018. "Pengaruh Kepemimpinan Transformasional terhadap Peningkatan Kualitas Kinerja Pegawai." Gorontalo Journal of Public Administration Studies 1(1): 55-68.

DOI: https://doi.org/10.32662/gjpads.v1i1.179

Pradini, Septalina. 2016. "Pesantren Transformation System in The Food Sustainability." International Journal of Development and Economic Sustainability 4(2): 1-18.

Ramdan, Ahmad and Maman Usman. 2021. "Pola Interaksi dan Komunikasi Kiai terhadap Santri di Pesantren Sirnarasa." Iktisyaf: Jurnal Ilmu Dakwah dan Tasawuf 3(1): 56-85.

Saefullah, U. 2012. Manajemen Pendidikan Islam. Bandung: Pustaka Setia.

Senny, Mei Hardika, Lanny Wijayaningsih, and Mozes Kurniawan. 2018.

"Penerapan Gaya Kepemimpinan Transformasional Dalam Manajemen PAUD.” Scholaria: Jurnal Pendidikan Dan Kebudayaan 8(2): 197-209.

DOI: https://doi.org/10.24246/j.js.2018.v8.i2.p197-209

Setiawan, Eko. 2013. "Modernisasi Pola Sistem Pendidikan Pesantren (Studi Kasus Pondok Pesantren Modern Daarul Fikri Mulyoagung Dau Malang)." ULUL ALBAB Jurnal Studi Islam 14(2): 176-93.

DOI: https://doi.org/10.18860/ua.v14i2.2656.

Steenbrink, Kareel. 1986. Pesantren, Madrasah, Sekolah. Jakarta: LP3ES.

Suhartina, Suhartina. 2020. "Pola Interaksi Kiai Dalam Membentuk Karakter Santri di Pesantren Ash-Shiddiqi Putri Talangsari.” Al-Ashr: Jurnal Pendidikan dan Pembelajaran Dasar 5(1): 122-51.

Susanto, Edi. 2017. "Kepemimpinan Kharismatik Kiai dalam Perspketif Masyarakat Madura." Karsa: Journal of Social and Islamic Culture 11(1): $30-40$.

DOI: https://doi.org/10.19105/karsa.v11i1.146 
Syafi'i, Syafi'i. 2019. "Peran Kepemimpinan Kiai Dalam Meningkatkan Mutu Pendidikan (Studi Kasus Di Pondok Pesantren Bahrul Maghfiroh Kota Malang).” Leadership:Jurnal Mahasiswa Manajemen Pendidikan Islam 1(1): 18-35.

DOI: https://doi.org/10.32478/leadership.v1i1.318.

Weber, Max. 1978. Economy and Society. Berkeley: University of California Press.

Yukl, Gary. 1999. "An Evaluation of Conceptual Weakness in Transformantional and Charismatic Leadership." Leadership Quarterly 10(2): $285-305$.

DOI: https://doi.org/10.1016/S1048-9843(99)00013-2 